\title{
Transesterification of Soybean Oil to Biodiesel by Anionic and Cationic Ion Exchange Resins
}

\author{
Oliveira, E. V. A.; Costa, L. C.; Thomaz, D. M.; Costa, M. A. S.; Santa \\ Maria, L. C.*
}

Rev. Virtual Quim., 2015, 7 (6), 2314-2333. Data de publicação na Web: 6 de setembro de 2015

http://www.uff.br/rvq

\section{Transesterificação de Óleo de Soja para Biodiesel Via Resinas de Troca lônica Catiônica e Aniônica}

\begin{abstract}
Resumo: Este trabalho reporta os resultados da avaliação das resinas comerciais Amberlyst 15 Wet (resina catiônica) e Amberlyst-260H (resina aniônica), ambas de estrutura macroporosa, na reação de transesterificação de óleo de soja com metanol e etanol. A influência das condições reacionais, tais como o tipo e quantidade de catalisador, tempo de reação, razão molar álcool e óleo foram investigadas. A resina aniônica mostrou-se mais eficiente do que a resina catiônica para a produção de EMAGs (ésteres metílicos de ácidos graxos) e EEAGs (ésteres etílicos de ácidos graxos). A conversão de óleo de soja em EMAGs empregando a resina aniônica foi de $100 \%$, usando $12,5 \mathrm{~mol} \%$ de resina, razão metanol:óleo 100:1 e tempo reacional de 8 horas. Os ésteres metílicos puderam ser classificados como biodiesel de acordo com as normas das Agência Nacional de Petróleo, Gás Natural e Biodiesel (ANP), normas europeias (EM) e Sociedade Americana para Testes e Materiais (ASTM): ANP 14 (2012), ANP 07 (2008), ASTM 6751(2008) e EN 14214 (2003). Para os ésteres etílicos, alguns parâmetros como viscosidade, teor de água e de glicerina necessitam ser otimizados.
\end{abstract}

Palavras-chave: Transesterificação; resinas de troca iônica; óleo de soja; biodiesel.

\begin{abstract}
This work reports the results of the evaluation of the commercial resins Amberlyst 15Wet (cationic resin) and Amberlyst-26OH (anionic resin), both with macroporous structures, on batch transesterification reactions of Brazilian soybean oil with methanol and ethanol. The influence of reaction conditions, such as type and amount of catalyst, reaction time and alcohol to oil molar ratio were investigated. The anionic resin was more efficient than the cationic resin for production of FAME (fatty-acid methyl esters) and FAEE (fatty-acid ethyl esters). The soybean oil conversion into FAME by employing the anionic resin was $100 \%$ employing $12.5 \mathrm{~mol} \%$ of resin, methanol to soybean oil mole ratio of 100:1 and reaction time of $8 \mathrm{~h}$. The methyl esters produced can be classified as biodiesel according to the standards of the Brazilian National Petroleum, Natural Gas and Biofuels Agency (ANP), European Standards (EN) and American Society for Testing and Materials (ASTM): ANP 14 (2012), ANP 07 (2008), ASTM 6751(2008) and EN 14214 (2003). For ethyl esters, some parameters, such as viscosity, water content and total glycerin, need to be optimized.
\end{abstract}

Keywords: Transesterification; ion exchange resins; soybean oil; biodiesel.

* Universidade do Estado do Rio de Janeiro, Instituto de Química, Departamento de Química Orgânica, Rua São Francisco Xavier 524, Maracanã, CEP 20550-900, Rio de Janeiro-RJ, Brasil.

MIcsantamaria@terra.com.br DOI: $\underline{10.5935 / 1984-6835.20150138}$ 


\section{Transesterification of Soybean Oil to Biodiesel by Anionic and Cationic lon Exchange Resins}

\section{Erica V. A. Oliveira, ${ }^{\mathrm{a}}$ Luciana C. Costa, ${ }^{\mathrm{b}}$ Dominiki M. Thomaz, ${ }^{\mathrm{c}}$ Marcos A. S. Costa, ${ }^{\mathrm{c}}$ Luiz C. Santa Maria ${ }^{\mathrm{c}, *}$}

${ }^{a}$ Agência Nacional do Petróleo e seus derivados, Gás Natural e Biocombustíveis.

${ }^{b}$ Centro Universitário Estadual da Zona Oeste, Centro Setorial de Ciências Biológicas e da Saúde, Avenida Manuel Caldeira de Alvarenga 1203, CEP 23070-200, Campo Grande, Rio de Janeiro-RJ, Brazil.

' Universidade do Estado do Rio de Janeiro, Instituto de Química, Departamento de Química Orgânica, Rua São Francisco Xavier 524, Maracanã, CEP 20550-900, Rio de Janeiro-RJ, Brasil.

* Icsantamaria@terra.com.br

Recebido em 28 de março de 2015. Aceito para publicação em 2 de setembro de 2015

1. Introduction

\section{Experimental Part}

2.1. Chemicals

2.2. Characterization of the Commercial Resins and Soybean Oil

2.3. Transesterification of Soybean Oil

2.4. Analysis of Biodiesel

\section{Results and Discussion}

3.1. Characterization of Soybean Oil and Ion Exchange Resins

3.2. Influence of Reaction Parameters on Conversion of Soybean Oil to FAME and FAEE

\subsection{Analysis of the Ester Products}

\section{Conclusions}

\section{Introduction}

The increasing demand for energy and growing environmental awareness have prompted a good deal of research into the production of substitute fuels from renewable resources which are environmentally more suitable. Biodiesel is an excellent replacement for fossil fuels due to its low emission of particulate matter and greenhouse gases such as $\mathrm{CO}_{\mathrm{x}}, \mathrm{NO}_{\mathrm{x}}$ and $\mathrm{SO}_{\mathrm{x}}$.

Biodiesel can be produced by esterification of fatty acids or transesterification of oils and fats with alcohols. ${ }^{1-6}$ More commonly, vegetable oils comprising a complex mixture of triglycerides (TG) and other minor components, such as 
free fatty acids (FFA), gums, waxes, etc., are subjected to transesterification with lowmolecular weight alcohols, usually methanol and ethanol, generating fatty-acid methyl esters (FAME) and fatty-acid ethyl esters (FAEE) in the presence of chemical or enzymatic catalysts. ${ }^{2-6}$ Alternatively, vegetable oils can also be mixed with diesel fuel and used directly, submitted to thermal cracking (pyrolysis) or generate microemulsions. ${ }^{2,7}$ Commercially, the transesterification reaction is carried out using homogeneous bases (sodium or potassium hydroxide). Nevertheless, these homogeneous catalysts are corrosive and not reusable. Also, the recovery of glycerin is difficult and the wastewater produced needs to be treated. ${ }^{1,4,7}$

To minimize the disadvantages related to use of homogeneous catalysts, several heterogeneous catalysts such as clays, zeolites, oxides and polymer resins have been evaluated for transesterification of vegetable oils. ${ }^{1,4,7}$ The principal advantage of ion exchange resins over other heterogeneous catalysts is related to the preparation of "tailor-made" materials by controlling the polymerization conditions. ${ }^{8}$ It is possible to prepare polymeric resins with different particle size and porosity degree by varying the organic and aqueous phase ratio, divinyl monomer content, type of diluent and dilution degree, agitation velocity, reaction temperature, etc. In addition, a wide variety of functional groups can be introduced in these polymeric resins, which have allowed the preparation of several different materials. According to $\mathrm{Li}$ and colleagues ${ }^{1}$, ion-exchange resins are more easily separated from the biodiesel product because of the relatively larger particle size.

Shibasaki-Kitakawa and colleagues ${ }^{9}$ and $\mathrm{Li}$ and colleagues ${ }^{1}$ studied the transesterification of oils with ethanol and methanol catalyzed by different types of ion exchange resins. In these works the catalytic activity of cationic and anionic resins was compared and in general the anionic resins were more efficient than cationic resins in the reactions studied. Although these studies demonstrate that anion exchange resins are efficient for transesterification of vegetable oils, the employment of this type of resin has not been sufficiently explored compared to the use of cationic resins, especially sulfonic resins. ${ }^{8,10-13}$ The use of alkaline catalysts for transesterification of oils has a serious limitation associated with production of soaps through free fatty acid neutralization or triglyceride saponification. Heterogeneous catalysts do not have this limitation. ${ }^{1,7}$

Most scientific articles about the employment of heterogeneous catalysts, especially polymeric resins, for transesterification reaction of vegetable oils are concerned with development of new catalysts and the influence of reaction parameters on the yield of esters. ${ }^{1,8-12}$ There has been insufficient analysis of these products according to the regulatory standards used to classify biodiesel. Thus, we evaluated the employment of two cationic and anionic resins: Amberlyst $15 \mathrm{Wet}$ (containing sulfonic acid groups) and Amberlyst-26OH (containing amine quaternary groups) associated with free hydroxyl ions on the batch transesterification reactions of Brazilian soybean oil with methanol and ethanol. The main factors affecting the transesterification reactions, such as reaction temperature, alcohol:oil molar ratio and amount of catalyst were investigated. To classify these products as biodiesel, we also analyzed the FAME and FAEE esters obtained in this work according to the following Brazilian, European and American standards: ANP 14 (2012), ANP 07 (2008), ASTM 6751(2008) and EN 14214 (2003). ${ }^{14-17}$

\section{Experimental Part}

\subsection{Chemicals}

Commercial soybean oil was purchased from Vila Velha S.A. (Rio de Janeiro, Brazil) and used without further purification. The resins Amberlyst $15 \mathrm{Wet}$ and Amberlyst- $26 \mathrm{OH}$ 
were kindly donated by Rohm and Haas Química Ltda. (São Paulo, Brazil). Prior to use, the resins were treated with an aqueous solution of $1.0 \mathrm{~mol} \mathrm{~L}^{-1} \mathrm{HCl}$ and $2.0 \mathrm{~mol} \mathrm{~L}^{-1} \mathrm{KOH}$ for $24 \mathrm{~h}$, respectively, and then washed with deionized water until neutral $\mathrm{pH}$ and acetone

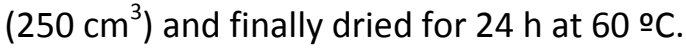

Methanol and ethanol (PA grade) were purchased from Vetec Química Fina Ltda. (Rio de Janeiro, Brazil) and were previously dried with a molecular sieve (10-20 mesh, Fluka) before use. Other reagents and solvents were purchased from Vetec Química Fina Ltda. (Rio de Janeiro, Brazil) and used as received.

\subsection{Characterization of the Commercial Resins and Soybean Oil}

The commercial soybean oil used in this work was characterized according to the standards of the AOCS (American Oil Chemists Society) ${ }^{18}$ by determining acidity (Cd 3a-63 method), ${ }^{18,19}$ saponification degree (TI 1A-64 method), ${ }^{18,19}$ free fatty acid content (Ca 5a-40 method), ${ }^{18,20}$ kinematic viscosity (kinematic viscosimeter CT2000) ${ }^{18,21}$ specific mass (Antopar densimeter DNA4500), 18, 22 and water content (Karl Fischer Ca-2e-84 method). ${ }^{18,19}$ The oil was also characterized by FTIR and ${ }^{1} \mathrm{H}$ NMR.

The resins were characterized by determining the apparent density by the graduated cylinder method, ${ }^{23}$ and the surface area and the pore volume distribution were assessed by nitrogen adsorption measurements following the BET and BJH methods, respectively (Micromeritcs, ASAP 2010 apparatus). The swelling capacity in methanol, ethanol and water was also determined. ${ }^{24}$ The beads' morphology was evaluated by scanning electron microscopy (JEOL-JSM 6460 LV). The ion exchange capacity was determined by acid-base titulation. ${ }^{25}$

\subsection{Transesterification of Soybean Oil}

The transesterification reactions of soybean oil were carried out in $250 \mathrm{~mL}$ threenecked flasks equipped with reflux condensers and magnetic stirrers. The resins were previously swollen in alcohol for $24 \mathrm{~h}$ before the experiments. Then $50 \mathrm{~g}$ of the oil was added under stirring into the flasks and the mixture was heated to the reaction temperature.

The molar ratio of alcohol (methanol or ethanol) to oil was 50:1, 100:1 or 150:1, and the resin amount varied from 12.5 to 50.0 mol\%. The temperature of the reaction media was kept constant at 65 으 for methanol and 78 o $\mathrm{C}$ for ethanol (the reflux temperatures of the reaction media).

After the reaction, the solid catalyst was separated by filtration. The liquid phase produced by both reactions was put into a separating funnel and was kept at room temperature for $24 \mathrm{~h}$, after which two phases appeared. The samples were washed with deionized water $\left(50 \mathrm{~cm}^{3}\right)$ and the organic phase was extracted with hexane $\left(15 \mathrm{~cm}^{3}\right)$ and dried with anhydrous magnesium sulfate. ${ }^{8,9,12}$

\subsection{Analysis of Biodiesel}

As suggested in the literature, ${ }^{26}$ the samples (10-50 $\mathrm{mg}$ of samples dissolved in $0.6 \mathrm{~cm}^{3}$ of $\mathrm{CDCl}_{3}$ ) were submitted to ${ }^{1} \mathrm{H} \mathrm{NMR}$ (Bruker Avance DPX-200 spectrometer, 4.7 Tesla, observation frequency of $200 \mathrm{MHz}$ ) by using tetramethylsilane as internal standard.

The conversion of TG into methyl esters was determined by using the ratio between the peaks of the methyl hydrogen (3.65 ppm) and methylene glycerol (4.05 and $4.40 \mathrm{ppm}$ ), according to Equation 1.

$$
R(\%)=100\left[\left(2 \mathrm{CH}_{3}\right)\left(3 \mathrm{CH}_{2}\right)\right]
$$


Where $\mathrm{R}(\%)$ : percentage of conversion of triglycerides into methyl esters, $\mathrm{CH}_{3}$ : peak area corresponding to methyl ester, $\mathrm{CH}_{2}$ : peak area corresponding to methylene or glycerol.

To determine the conversion of TG into ethyl esters, the following equation (Equation 2) was used, according to Saytyarthi and colleagues. ${ }^{20}$

$$
R(\%)=100\left[\left(\frac{A 1-A 2}{A 3}\right)\right]
$$

Where $R(\%)$ : percentage of conversion of triglycerides into ethyl esters, $\mathrm{A} 1$ : peak area corresponding to the quartet, $\mathrm{A} 2$ : peak area corresponding to the double doublet, A3: peak area of the triplet.

The contents of monoglycerides, diglycerides, tryglycerides, free glycerin and total glycerin were determined by CG-MAS (Shimadzu, model GC 2010). The chromatograph was equipped with a flameionization detector (FID) and high-resolution capillary column of $5 \%$ phenylpolydimethylsiloxane (DB5-HT) (15 m x $0.32 \mathrm{~mm} \times 0.1 \mu \mathrm{m}$ ) according to the ASTM D $6584,{ }^{27}$ EN $14105^{28}$ and ABNT NBR 15341, ${ }^{29}$ $15342,{ }^{30} 15344,{ }^{31} 15771^{32}$ standards.

The oven and injector were submitted to the following temperature program. Injector: the temperatures were set at $60 \stackrel{\circ}{\circ}$ and 380 o $C$ at heating rates of 60 and $20 \stackrel{\circ}{ } \mathrm{C} \mathrm{min}^{-1}$. Oven: the temperatures were set at 50,180 ,

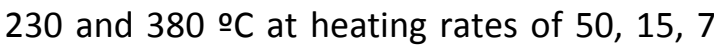
and $30 \stackrel{\circ}{ } \mathrm{C} \mathrm{min}^{-1}$. The detector temperature was set at $380 \stackrel{\circ}{\circ}$. The injection volume was $1 \mu \mathrm{L}$ and hydrogen was used as carrier gas at a flow rate of $3 \mathrm{~cm}^{3} \mathrm{~min}^{-1}$. The total analysis time was 30 minutes.

The ester content was determined according to ASTM D 6584, ${ }^{27}$ EN $14103^{33}$ and ABNT NBR $15764^{34}$ by employing a capillary column of polyethylene glycol (Carbowax $20 \mathrm{M}, 30 \mathrm{~m} \times 0.32 \mathrm{~mm} \times 0,25 \mu \mathrm{m})$. The oven and injector were submitted to a temperature program where the temperatures were set at $50 \circ \mathrm{C}, 180,230$ and

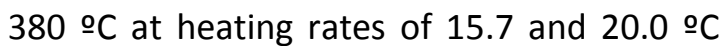
$\mathrm{min}^{-1}$. The detector temperature was set at $250 \stackrel{\circ}{\circ}$. Hydrogen and helium were used as carrier gas at a flow rate of $30 \mathrm{~cm}^{3} \mathrm{~min}^{-1}$.

The methanol and ethanol contents were determined according to EN $14110^{35}$ and ABNT NBR $15343^{36}$ by employing a capillary column of methyl silicone $(30 \mathrm{~m} \times 0.32 \mathrm{~mm} \times$ $3 \mu \mathrm{m})$. The oven temperatures were set at 50

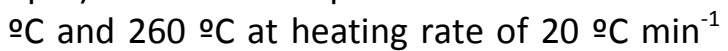
for times of 6 and 50 minutes respectively. The FID detector temperature was set at 260 oc. The injection volume was $1 \mu \mathrm{L}$ and hydrogen was used as carrier gas at a flow rate of $3 \mathrm{~cm}^{3} \mathrm{~min}^{-1}$.

The biodiesel product was also characterized by FTIR in a Perkin-Elmer (Spectrum One) spectrometer (wavenumber range $4000-400 \mathrm{~cm}^{-1}, 4$ scans and $4 \mathrm{~cm}^{-1}$ resolution). Furthermore, the biodiesel was characterized by determining its bulk density, ${ }^{22,37,38}$ acidity, $^{39-41}$ kinematic viscosity, ${ }^{21,42,43}$ water content ${ }^{44,45}$ and iodine index ${ }^{46}$ according to test methods sat by the ANP, American Society for Testing and Materials and European standards. ${ }^{14-17}$

\section{Results and Discussion}

The Brazilian soybean oil used in this work was characterized by FTIR and ${ }^{1} \mathrm{H}$ NMR (Figure 1 ) to obtain the saponification degree, acidity, free fatty acid content, kinematic viscosity, specific mass and water content (Table 1). 
Table 1. Physical-chemical characteristics of the soybean oil used in this work

\begin{tabular}{|l|l|}
\hline Parameters & Soybean oil \\
\hline Acidity $\left(\mathrm{mg} \mathrm{KOH} \mathrm{g}^{-1}\right)$ & 0.22 \\
\hline Free fatty acid $/ \%$ & 0.16 \\
\hline Saponification degree $\left(\mathrm{mg} \mathrm{KOH} \mathrm{g}^{-1}\right)$ & 200.70 \\
\hline Viscosity at $37.8^{\circ} \mathrm{C} / \mathrm{cSt}$ & 36.80 \\
\hline Specific Mass $\left(\mathrm{g} \mathrm{cm}^{-3}\right)$ & 0.92 \\
\hline Water content $/ \%$ & 0.07 \\
\hline
\end{tabular}

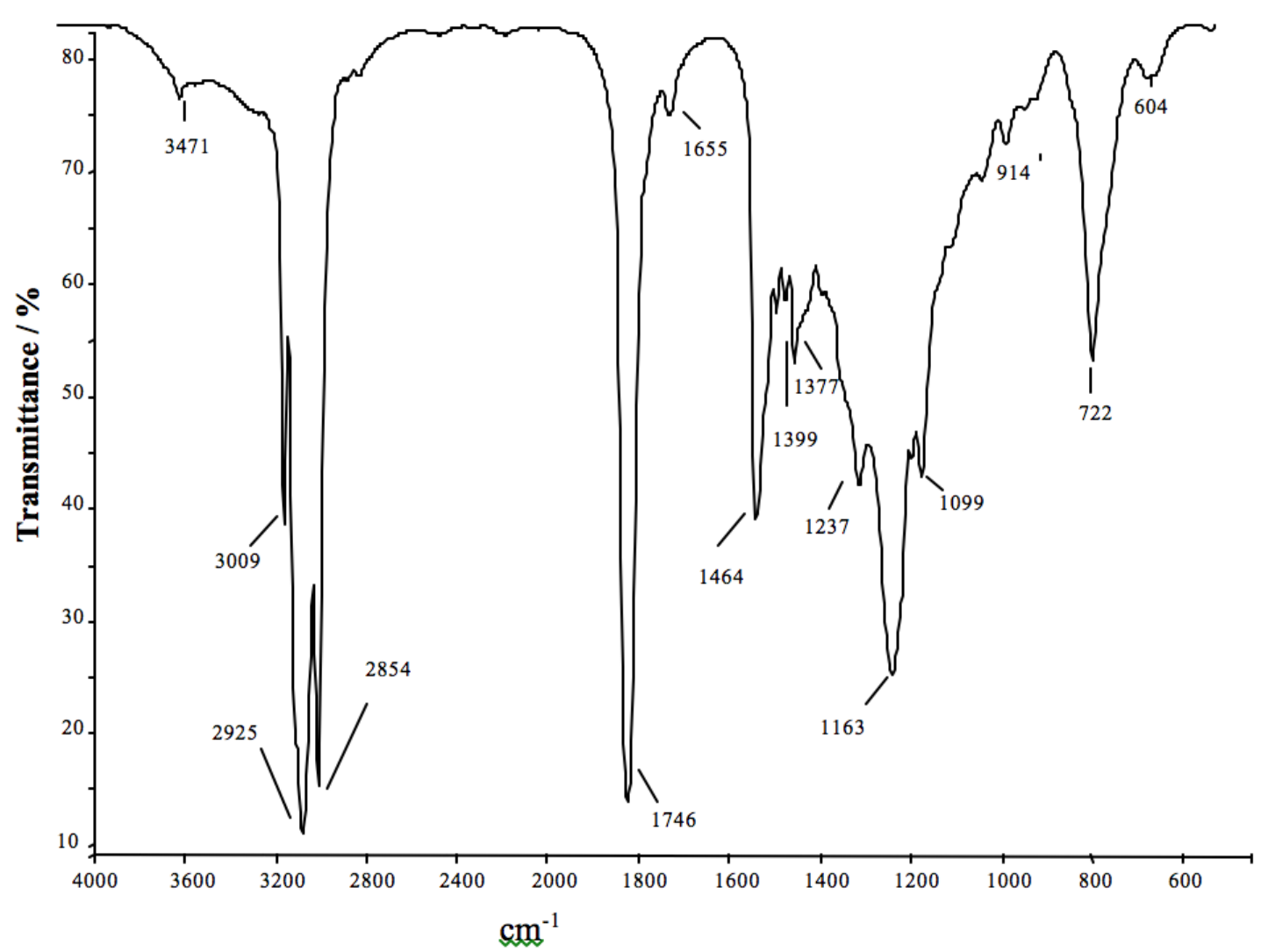

(a) 


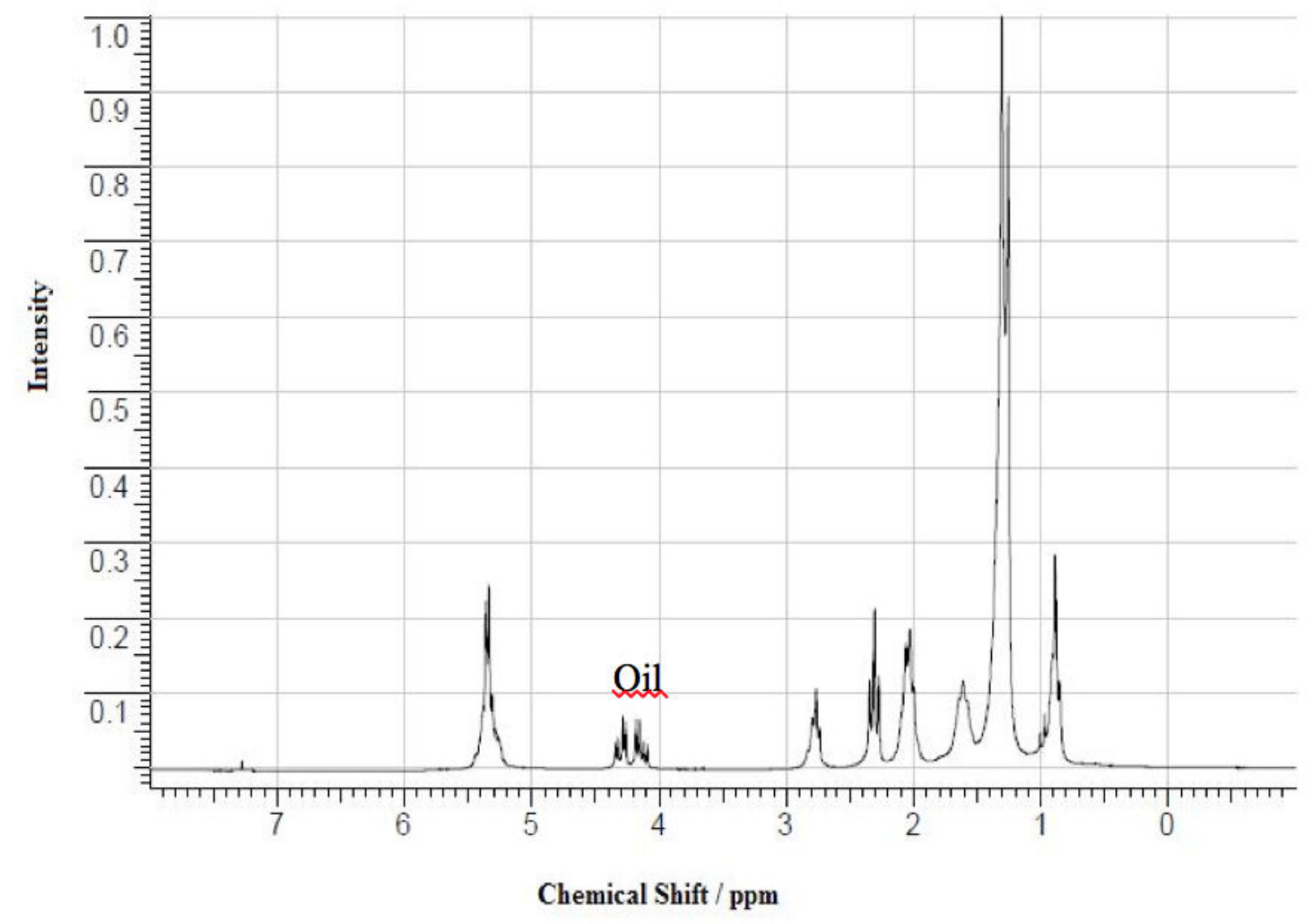

(b)

Figure 1. FTIR (a) and ${ }^{1} H$ NMR (b) spectra of the Brazilian soybean oil

The data obtained from the FTIR and ${ }^{1} \mathrm{H}$ NMR spectra are according to the literature and indicate that the soybean oil is composed mainly of esters derived from linoleic and oleic acids. ${ }^{7,8}$ The FTIR spectrum of soybean oil shows bands at $3009-2854 \mathrm{~cm}^{-1}$ due to vas $\mathrm{CH}_{3}$, vs $\mathrm{CH}_{3}$, vas $\mathrm{CH}_{2}$, a band at $1464 \mathrm{~cm}^{-1}$ due to vs $\mathrm{CH}_{2}$, indicating the presence of long carbon chains, and a strong band at $1746 \mathrm{~cm}^{-}$ 1 ascribed to $\mathrm{C}=\mathrm{O}$ stretching vibration of esters, as well as bands at 1300 and $1100 \mathrm{~cm}^{-}$ 1 related with two asymmetrical coupled vibrations $\mathrm{C}-\mathrm{C}(=\mathrm{O})-\mathrm{O}$ and $\mathrm{O}-\mathrm{C}-\mathrm{C}$. The low band at $3471 \mathrm{~cm}^{-1}$ due $\mathrm{OH}$ stretching and the absence of bands at $1315-1280 \mathrm{~cm}^{-1}$ related with $\mathrm{C}-\mathrm{O}$ stretching and the absence of bands at $920 \mathrm{~cm}^{-1}$ due $\mathrm{OH}$ out-of-plane bend indicate a low content of free fatty acids in the soybean oil, which is confirmed by acidbase titration with $\mathrm{NaOH}$ (Table 1). ${ }^{47}$ In the ${ }^{1} \mathrm{H}$ NMR spectrum of the soybean oil, the main region is located between 4.0-4.4 ppm, related to the coupling of the four methylene hydrogen atoms with methylene hydrogen of triglycerides, resulting in a double-doublet. ${ }^{7,47}$ Beside low content of free fatty acids, the Brazilian soybean oil possesses low acidity and water content (Table 1), indicating this oil is adequate for biodiesel production. ${ }^{7}$ The transesterification reaction of TG is directly influenced by oil quality, mainly by free fatty acid content, which can promote saponification when this reaction is carried out with a basic catalyst.

The features of the porous structure of the ion exchange resin have a strong influence on the catalytic activity of the resin. Several works demonstrate that the catalytic activity of ion exchange resins is influenced by the distribution, local concentration of the active groups in polymer matrix and access of the reactant molecules to these active groups. ${ }^{1,9-13}$ Taking this into account, we 
chose to evaluate as catalysts two ion exchange resins with macroporous structures. The presence of pores permits access of reactant molecules into the inner structure of the polymeric network, where the number of active sites is much higher than on the surface of the beads. ${ }^{48}$ The principal characteristics of these resins are shown in Table 2.

Table 2. Morphological characteristics, swelling degree and ion exchange capacity of the ion exchange resins

\begin{tabular}{c|c|c|c|c|c|c|c|c}
\hline Resin & $\begin{array}{c}\mathrm{d}_{\mathrm{a}} \\
\left(\mathrm{g} \mathrm{cm}^{-3}\right)\end{array}$ & $\begin{array}{c}\mathrm{S}_{\mathrm{a}} \\
\left(\mathrm{m}^{2} \mathrm{~g}^{-1}\right)\end{array}$ & $\begin{array}{c}\mathrm{V}_{\mathrm{p}} \\
\left(\mathrm{cm}^{3} \mathrm{~g}^{-1}\right)\end{array}$ & $\begin{array}{c}\mathrm{D}_{\mathrm{p}} / \\
\AA\end{array}$ & $\begin{array}{c}\mathrm{I}_{\mathrm{MeOH}} / \\
\%\end{array}$ & $\begin{array}{c}\mathrm{I}_{\text {EtOH }} / \\
\%\end{array}$ & $\begin{array}{c}\mathrm{I}_{\mathrm{w}} / \\
\%\end{array}$ & $\begin{array}{c}\mathrm{E}_{\mathrm{C}} \\
\left(\mathrm{m}_{\text {eq }} \mathrm{g}^{-1}\right)\end{array}$ \\
\hline $15 \mathrm{Wet}$ & 0.56 & 30 & 0.27 & 250 & 42 & 44 & 48 & 5.2 \\
\hline $26 \mathrm{OH}$ & 0.58 & 14 & 0.12 & 310 & 126 & 113 & 93 & 1.3 \\
\hline
\end{tabular}

$\mathrm{d}_{\mathrm{a}}$ : bulk density, $\mathrm{S}_{\mathrm{a}}$ : specific area, $\mathrm{V}_{\mathrm{p}}$ : pore volume, $\mathrm{D}_{\mathrm{p}}$ : mean pore diameter, $\mathrm{I}_{\mathrm{MeOH}}$ : swelling in methanol, $\mathrm{I}_{\mathrm{EtOH}}$ : swelling in ethanol, $\mathrm{I}_{\mathrm{w}}$ : swelling in water, $\mathrm{E}_{\mathrm{c}}$ : ion exchange capacity

The macroporous structure of the resins is confirmed by the high pore diameter associated with low surface area and by analyzing the scanning electron micrographs of the internal part of the resins, which show the clusters of microspheres separated by larger pores (Figure 2). The experimental ion exchange capacities determined by acid-base titration were slightly higher than the data given by the manufacturer $\left(4.7 \mathrm{mEq}-\mathrm{g} \mathrm{g}^{1}\right.$ and $0.8 \mathrm{mEq}-\mathrm{g} \mathrm{\textrm {g } ^ { - 1 }}$ for Amberliste $15 \mathrm{Wet}$ and $260 \mathrm{H}$, respectively). The cationic resin presented higher ion exchange capacity than the anionic resin. The values of swelling capacity in water, ethanol and methanol indicate that the cationic resin has a more entangled structure than the anionic resin.

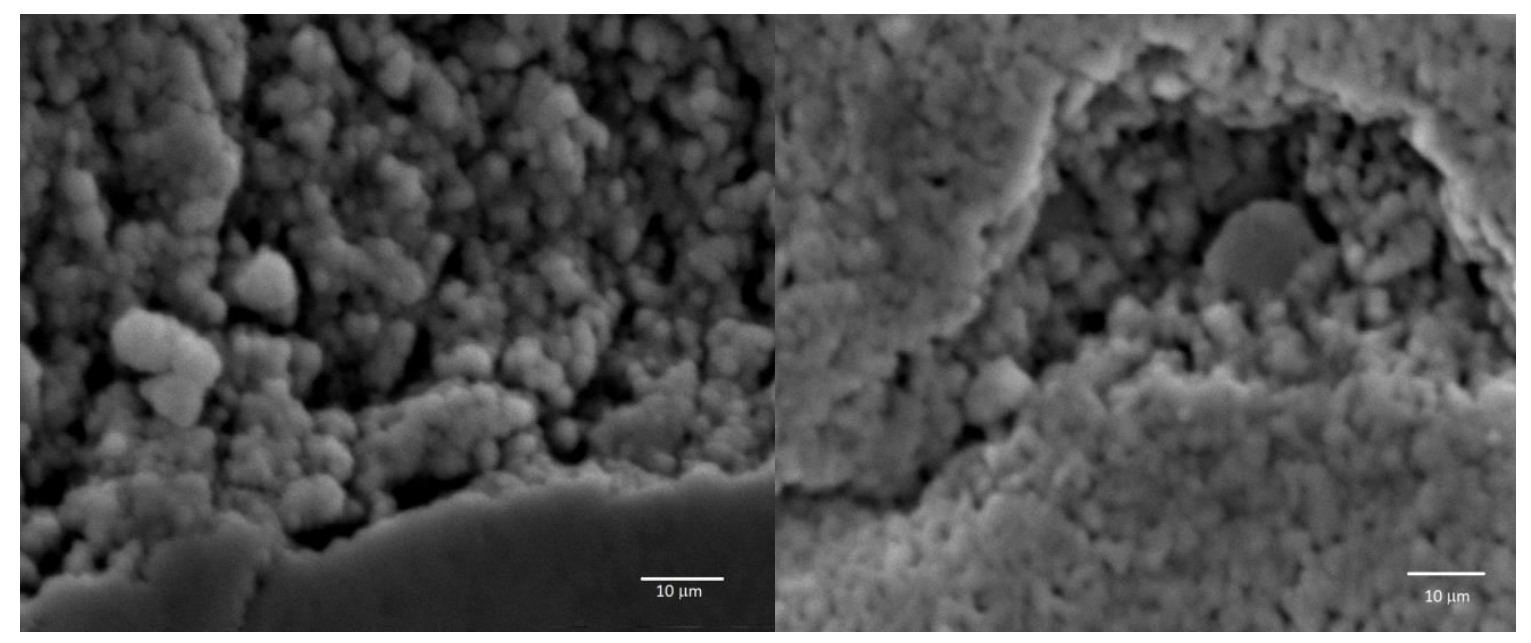

(a)

(b)

Figure 2. Scanning electron micrographs of the internal part of the resins Amberlyst $15 \mathrm{Wet}$ (a) and Amberlyst $260 \mathrm{H}$ (b) (magnification 20,000 x) 
3.2. Influence of Reaction Parameters on Conversion of Soybean Oil to FAME and FAEE

According to the stoichiometry, the transesterification reaction occurs with $1 \mathrm{~mol}$ of TG and $3 \mathrm{~mol}$ of alcohol. However, extra alcohol is generally employed to increase the yield of esters and to facilitate glycerin separation. ${ }^{49}$ In our first studies, we evaluated molar ratios of methanol or ethanol to oil of $6: 1,12: 1$ and 24:1, employing molar concentration of the catalysts of $12.5 \%$, reaction time of $24 \mathrm{~h}$ and varying the temperature between $45-90 \stackrel{\circ}{ }$. None of these reactions led to the formation of esters.

Thus, we evaluated three other methanol or ethanol to oil molar ratios $(50: 1,100: 1$ and 150:1) for synthesis of FAME and FAEE, employing the anionic resin, reaction time of $8 \mathrm{~h}$, temperatures of 65 and $78 \stackrel{\circ}{\circ}$, and concentration of the catalysts of $12.5 \mathrm{~mol} \%$ (Figure 3). The conversion of the oils (TG) into FAME and FAEE was followed by ${ }^{1} \mathrm{H}$ NMR spectrometry (Equations 1 and 2), according to Gelbard et al. ${ }^{26}$ and Saytyarthi et al. ${ }^{20}$

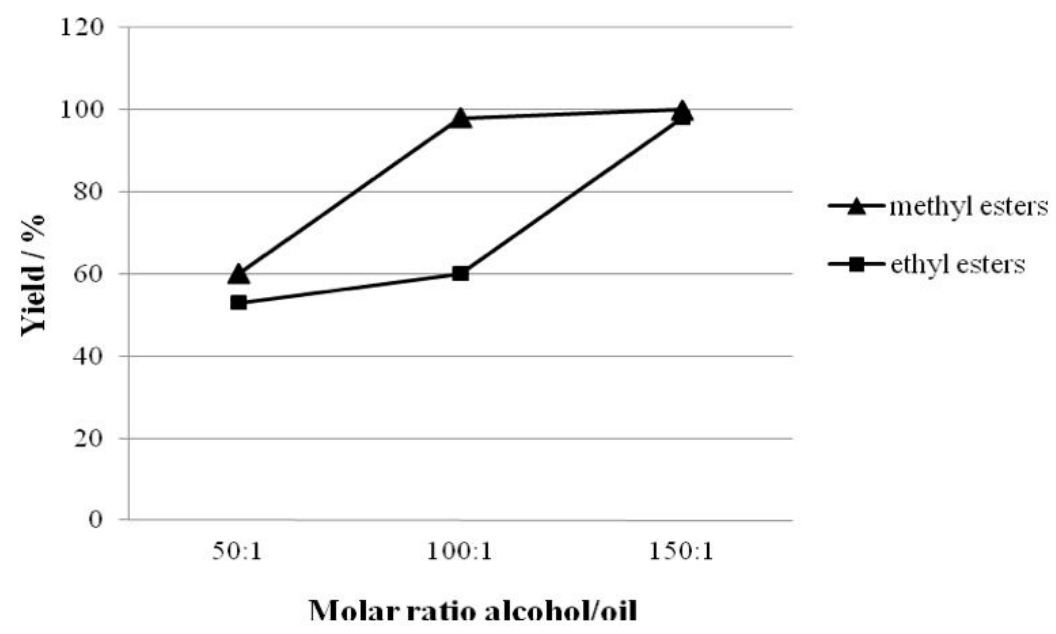

Figure 3. Influence of the alcohol:oil molar ratio on production of FAME and FAEE by the resin Amberlyst $260 \mathrm{H}$

Analyzing Figure 3 , it is possible to observe that the conversion degrees of FAME and FAEE of around $50 \%$ were achieved only by using an alcohol:oil molar ratio of 50:1. There was a substantial increase in conversion to FAEE when the alcohol: oil molar ratio passed from 100:1 to 150:1, but this increase was negligible for FAME. The transesterification with ethanol reached $100 \%$ conversion only at the highest molar ratio of 150:1. Ethanol is less reactive than methanol, so these results are also consistent with the relative reactivities of the two alcohols studied.

Our results agree with reports in the literature about the need for high alcohol:oil molar ratio for the transesterification of soybean oil with ethanol and methanol by employing ion exchange resins. Reis et al. ${ }^{12}$ employed commercial ion exchange resins with sulfonic groups for transesterification of several vegetable oil with methanol. The influence of alcohol:oil molar ratio was studied on transesterification of babaçu coconut oil with methanol employing Amberlyst 15 wet (Rohm and Haas Co.). The authors observed the need for high alcohol content to produce ester. The conversion degree of FAME reached around $70 \%$ only by employing an alcohol:oil molar ratio of 300:1. Rezende et $a l_{.}^{8}$ evaluated sulfonic resins for transesterification of babaçu oil with 
methanol. Conversion degree of around $100 \%$ was achieved by employing alcohol:oil of $50: 1$.

The continual generation of alcohol vapor during the transesterification reaction makes it necessary to use an alcohol:oil molar ratio higher than the theoretical value of 3:1. The need for a high alcohol:oil molar ratio for transesterification reactions catalyzed by ion exchange resins can also be explained by the limited mass transfer process of the reactants and products through the polymeric structure. ${ }^{1}$

Some researchers have adopted strategies to permit the transesterification reaction with ion exchange resins employing lower oil:alcohol ratios. $\mathrm{Li}$ and colleagues $^{1}$ studied the transesterification of yellow horn seed oil and methanol catalyzed by different types of ion exchange resins assisted by microwave irradiation. Microwave irradiation generates an electromagnetic field that accelerates the movements of molecules, favoring the reaction. In this work, the conversion degree of FAME reached around $100 \%$ employing a molar ratio methanol:oil of 22:1.

The effect of the quantity of catalyst on the conversion of soybean oil to FAME and FAEE esters was investigated by employing a weight concentration of the catalysts, based on the oil, ranging between $12.5 \mathrm{~mol} \%$ and $50 \mathrm{~mol} \%$, a molar ratio between alcohol:oil of 150:1, alcohol reflux temperatures of 65 으 and $78 \stackrel{\circ}{\circ}$ and reaction time of $8 \mathrm{~h}$ (Figure 4).

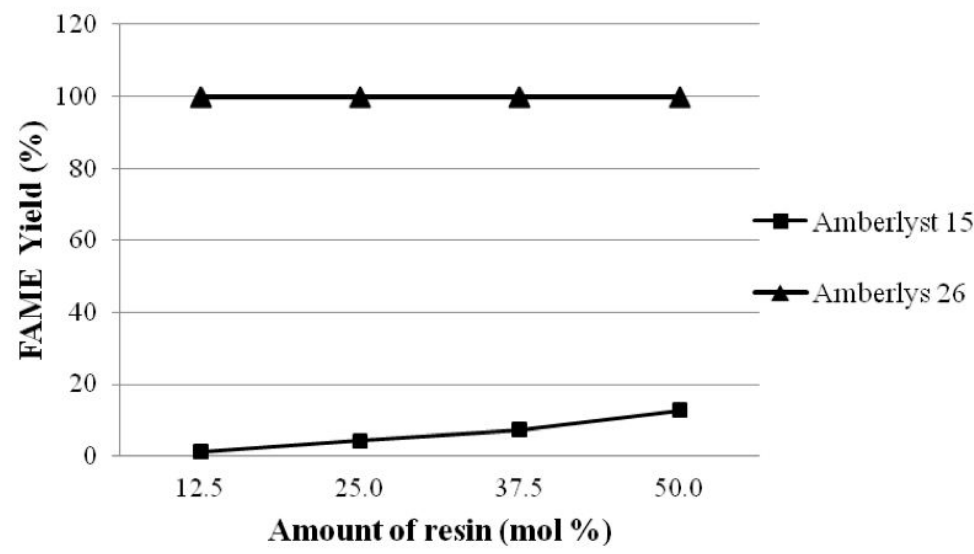

(a)

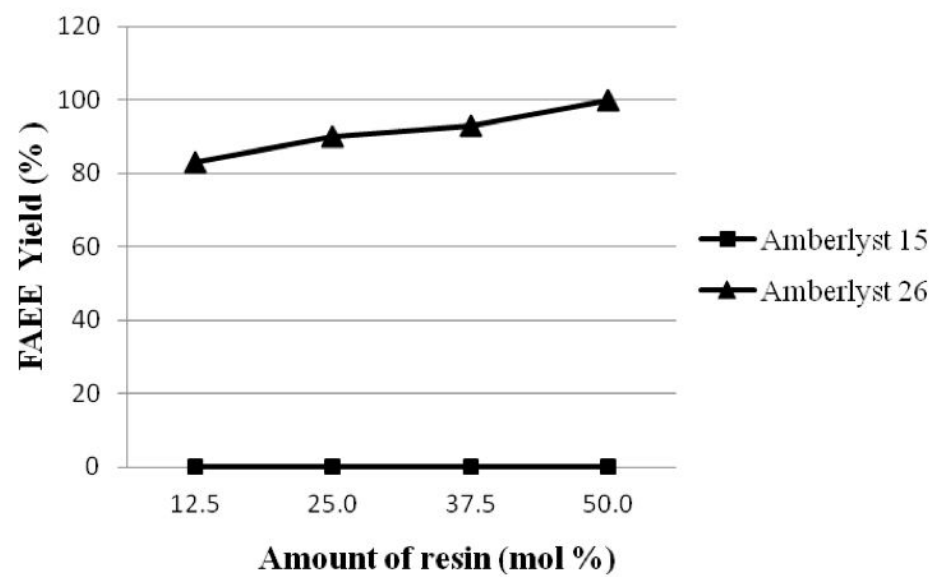

(b)

Figure 4. Effect of resin weight on conversion to FAME (a) and FAEE (b) 
The conversion of soybean oil to FAME by employing the anionic resin was $100 \%$, independent of the catalyst amount, whereas the conversion of oil to FAEE employing this resin increased from $50 \%$ to $80 \%$ by varying the amount of catalyst from 12.5 to $50 \mathrm{~mol}$ $\%$. In turn, for the cationic resin, conversion of oil to FAME of around $20 \%$ was obtained only by employing a concentration of resin of $50 \%$, so this resin was not efficient in conversion of oil to FAEE. This result is consistent with the relative reactivities of the two alcohols studied, since for this type of reaction, ethanol is less reactive than methanol. ${ }^{7}$ According to Schuchardt and colleagues, ${ }^{49}$ the use of methanol as alcohol is advantageous in transesterification reactions because it allows the simultaneous separation of glycerol. We observed gel formation (gelation of the whole system) after the end of the transesterification reaction with ethanol. The formation of soaps in the reaction medium can be attributed to the ester hydrolysis that occurred due to the presence of water, indicating that the drying of ethanol before the transesterification reactions was not fully successful. This is a negative point that can make the use of ethanol as alcohol source to produce biodiesel unfeasible on an industrial scale. ${ }^{7}$

The anionic resin Amberlyst-26OH showed high catalytic activity in converting oil to FAEE and FAME, whereas the cationic resin was not efficient in conversion of oil into both fatty-acid esters. These results do not agree with data of ion exchange capacity of these resins (Table 2). Analyzing these data, it is possible to observe that the cationic resin presented higher ion exchange capacity than anionic resin, which indicates that cationic resin possesses high content of active groups accessible to ion exchange. However also it is possible to observe that anionic resin present higher swelling capacity in both ethanol and methanol. According to Lotero et al.13, the catalytic activity of ion exchange resins is governed mainly by their swelling capacity, because this characteristic is related with reactants' accessibility through the polymeric matrix.
The catalytic action of the sulfonic resin was limited by the impossibility of adsorption of the ester molecules through the inner structure of this resin. As is well known, the action of this resin as catalyst is related to the increase of electrophilic activation of the carbonyl groups of TG, which favors the attack by the alcohol on these groups. Only the sulfonic groups located on the surface of the cationic resin are available to ester molecules due the high mass of these molecules. Thus, although this resin presented high ion exchange capacity, it did not present high catalytic activity in transesterification of soybean oil. Nevertheless, anionic resins act as catalysts by a different mechanism, abstracting protons from alcohol molecules to produce alkoxide ions, which in another step attack the carbonyl groups of TG. The diffusion of ethanol and methanol molecules through the anionic resin, and consequently their contact with carbonyl groups, is facilitated because of the low mass of these molecules combined with high swelling capacity of this resin in alcohols, favoring the action of this resin as a catalyst. $^{1,49}$

Anionic resins also have shown higher activity than cationic resins in other transesterification reactions, confirming the data observed in this work. ShibasakiKitakawa and colleagues ${ }^{9}$ reported the effects of anionic and cationic resins with different porosity degrees on the transesterification reaction of triolein with ethanol. The anionic resins with amine quaternary groups (Diaion PA308, PA306 and PA306s, HPA25) exhibited much higher catalytic activities than the cationic sulfonic resin evaluated (Diaion PK208). The anionic resin (PA306s) with low crosslinking density and small particle size promoted a high reaction rate as well as high conversion. The swelling capacity of these resins was not determined. Probably the resin PA306s had higher swelling capacity in ethanol because this resin presented low crosslinking degree.

Recently $\mathrm{He}$ et $a l^{50}$ developed a continuous process of biodiesel production from acidic oil containing soybean oil and 
oleic acid based on esterification reaction catalyzed by cationic resin, used for online separation and transesterification of the oil mixture (soybean oil and methyl esters) with anionic resin. The cationic and anionic resins evaluated were respectively NKC9 and D261, both obtained from Tianjin Kermel Chemical Reagent Co, China. Conversions of oleic acid above $98 \%$ and soybean oil of $92.3 \%$ were achieved. In the transesterification reaction, methanol:soybean and $\mathrm{n}$-hexane:soybean oil molar ratios of $1: 3$ and 1:2 were employed,

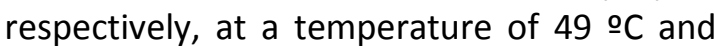
time of 112 minutes. This work is interesting because it analyzes the combination of cationic and anionic resins in the reaction and shows these resins are efficient.

The effect of reaction time on the conversion of oil to FAME and FAEE esters was investigated by employing a molar concentration of the catalysts of $12.5 \%$, alcohol:oil molar ratio of 150:1 and temperatures of $65{ }^{\circ} \mathrm{C}$ and $78 \stackrel{\circ}{\circ}$. It can be clearly seen (Figure 5) that the anionexchange resin successfully catalyzed the transesterification and produced FAME and FAEE with high conversion (almost 100\%). In fact, after six hours of reaction, high yields were obtained for both methanol and ethanol.

The FTIR and $\mathrm{H}^{1} \mathrm{NMR}$ spectra of the ethyl and methyl esters obtained by employing the anionic resin as catalyst are shown in Figures 6 and 7, respectively.

The main regions that set the two FTIR spectra apart are in the region of $1459-1436$ $\mathrm{cm}^{-1}$, which corresponds to the angular deformation of the symmetric methylene group $(\delta s \mathrm{CH} 2)$ of methyl and ethyl esters, the bands at 1196 and $1171 \mathrm{~cm}^{-1}$, which are attributed to asymmetric stretching vibrations of coupled CO (vas C-O) of methyl esters, and the band at $1179 \mathrm{~cm}^{-1}$, attributed to asymmetric stretching vibrations of coupled CO (vasC-O) of ethyl esters. ${ }^{47}$

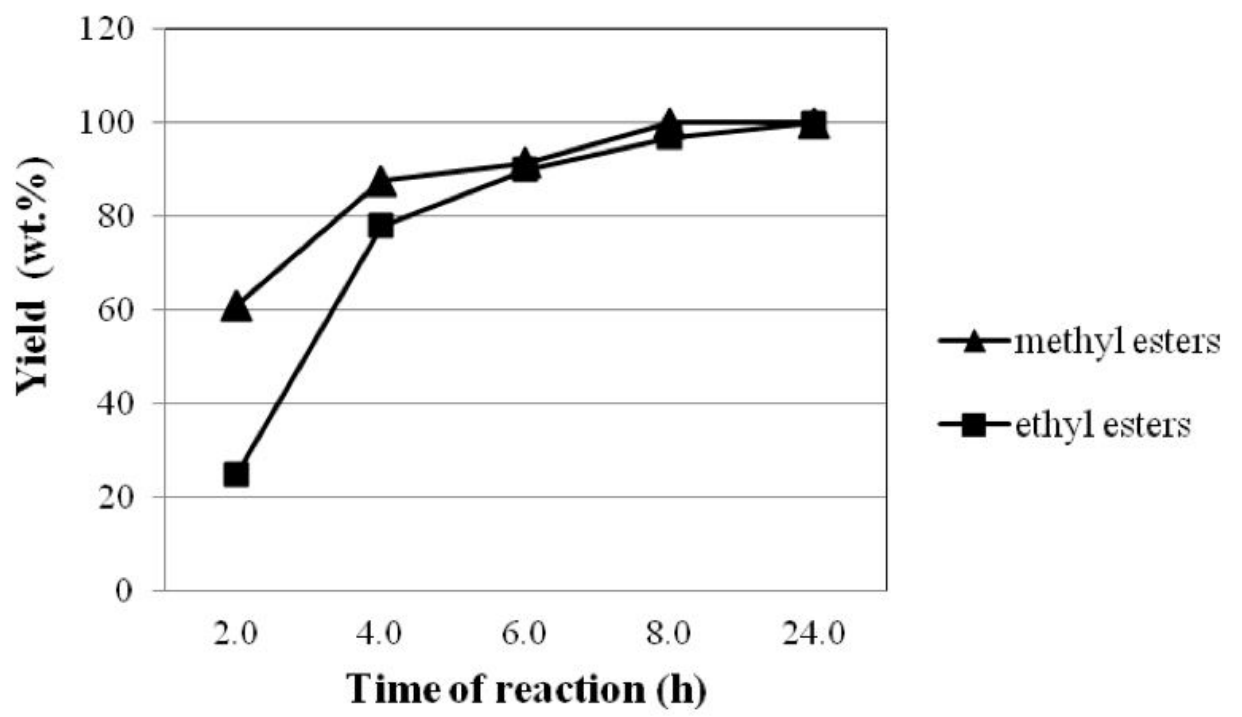

Figure 5. Yield versus reaction time of transesterification of soybean oil with resin and methanol or ethano 


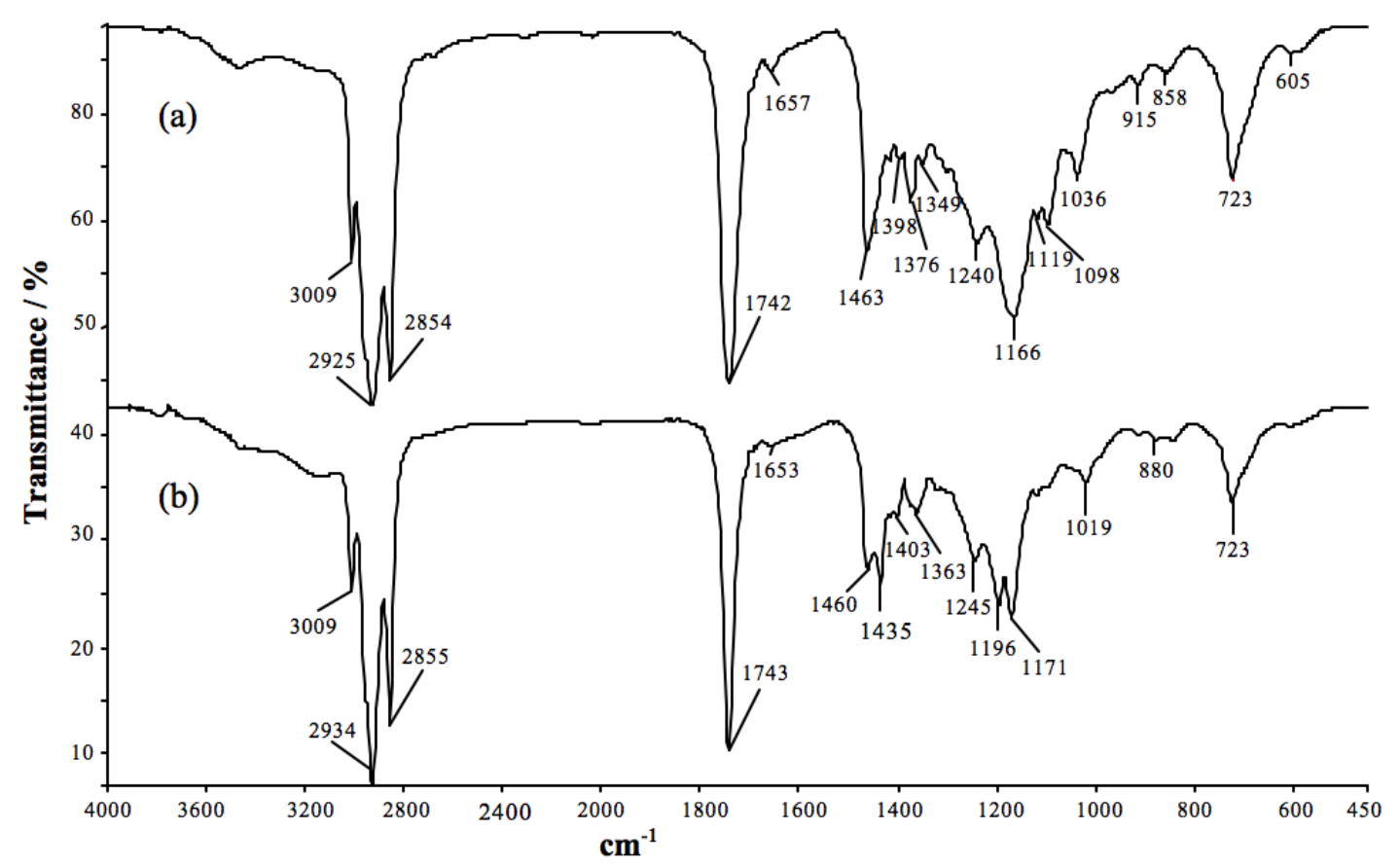

Figure 6. FTIR spectra of FAME (a) and FAEE (b) esters obtained from transesterification of soybean oil with the basic resin Amberlyst $260 \mathrm{H}$

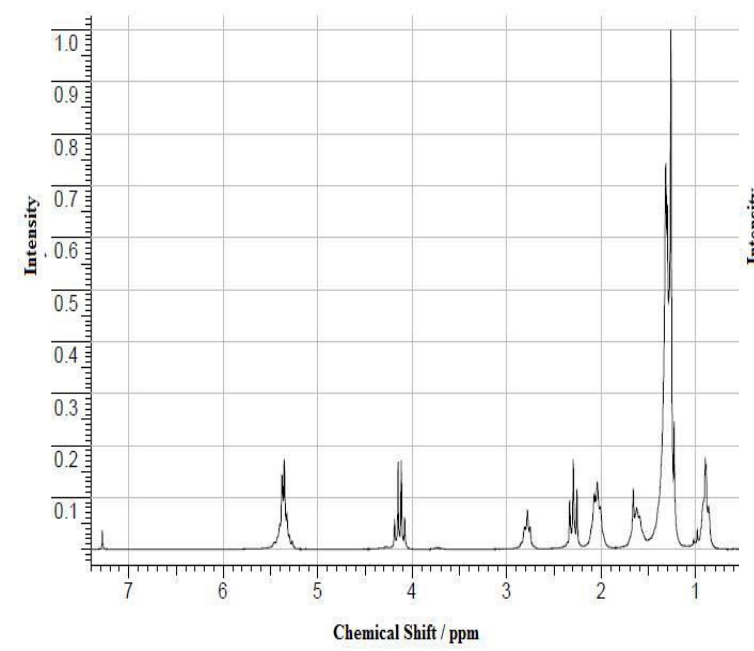

(a)

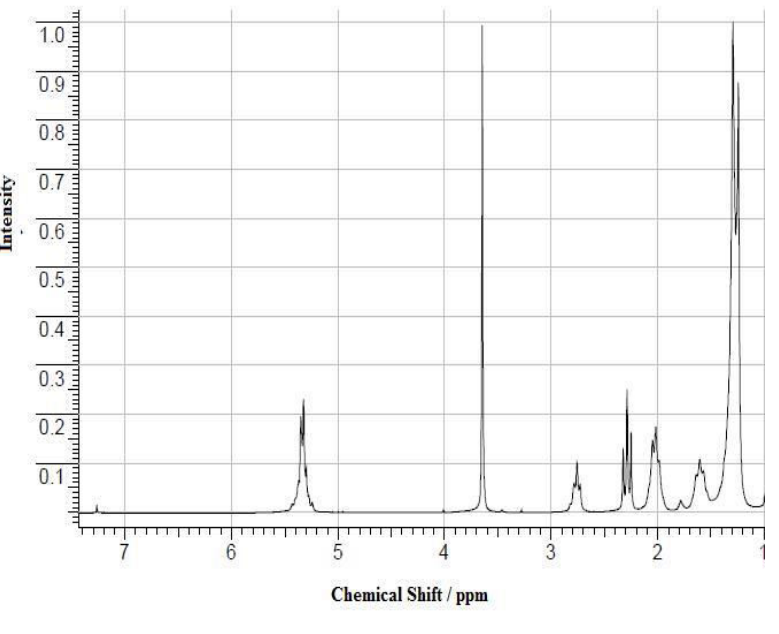

(b)

Figure 7. ${ }^{1} \mathrm{HNMR}$ spectra of FAME (a) and FAEE (b) esters obtained from transesterification of soybean oil with the basic resin Amberlyst $260 \mathrm{H}$

As commented before, the conversion of the oils into mixtures of fatty acid methyl esters (FAME) was determined by measuring the ratio through the areas of protons of hydrogens at 4.1-4.3 and 3.7 ppm in the ${ }^{1} \mathrm{H}$
NMR spectra. ${ }^{20}$ For the ethyl esters, more important than the signals is the quartet located in the region from 4.05 to $4.25 \mathrm{ppm}$, which represents the methylene hydrogen coupling of ethoxyl $\left(\mathrm{R}-\mathrm{COOCH}_{2} \mathrm{CH}_{3}\right)$ with its 
methyl group protons. ${ }^{26}$ In addition, the triplet corresponding to the coupling with the methyl group is observed as a signal at 1.25 ppm, which is typical of ethyl esters and can also be used to determine the ester content. Determination of ethyl ester content was difficult because the bands overlapped those of the ethyl esters of TG.

\subsection{Analysis of the Ester Products}

Several researches have evaluated the use of ion exchange resins for transesterification of vegetable oil in order to prepare biodiesel. These articles have studied the influence of the type and degree of porosity of the polymeric supports, type and content of ion exchange groups introduced on these supports and transesterification yields achieved. Many of these articles have studied the influence of reaction parameters, alcohol content, resin mass, temperature and transesterification reaction time. ${ }^{1,} \quad 8-12$ However, there has been insufficient analysis of the biodiesel produced by these transesterification reactions according to the regulatory standards.

Recently Shibasaki-Kitakawa et al. ${ }^{51}$ employed ion exchange resins for transesterification of an oil with high content of free fatty acids in a continuous process. The biodiesel obtained was characterized according to 26 specifications, such as acid value, water content, free and total glycerin, sulfur content, density, viscosity, etc., and the values obtained with these parameters were compared with the EN 14214 standard.

In this work, we analyzed the biodiesel produced according to four standards: Brazilian standards ANP 14 (2012) and ANP 07 (2008), American standard ASTM 6751(2008) and European standard EN 14214 (2003). ${ }^{14-17}$ We did not find these types of analysis in the literature.

The Brazilian standards ANP $14(2012)^{15}$ and ANP $07 \quad(2008) \quad 14$ contain 24 specifications. The American and European counterparts, ASTM $6751(2008)^{16}$ and EN $14214(2003),{ }^{17}$ contain 20 and 22 specifications respectively. We considered 12 specifications common to these standards to classify the products generated in this work as biodiesel. Table 3 shows the limits established in these standards for the 12 specifications investigated. Table 4 presents the characterization of the FAME and FAEE esters produced in this work.

Table 3. Principal specifications and limits of biodiesel established in ANP 14 (2012), ANP 07 (2008), ASTM 6751(2008) and EN 14214 (2003) 14-17

\begin{tabular}{|c|c|c|c|c|}
\hline \multirow[b]{2}{*}{ Characteristics } & \multicolumn{4}{|c|}{ Limits } \\
\hline & $\begin{array}{l}\text { RANP } \\
07-08 \\
\end{array}$ & $\begin{array}{l}\text { RANP } \\
14-12 \\
\end{array}$ & $\begin{array}{c}\text { ASTM D 6751- } \\
08 \\
\end{array}$ & $\begin{array}{c}\text { EN ISO } \\
14214-03 \\
\end{array}$ \\
\hline Bulk density ${ }^{a}\left(\mathrm{~kg} \mathrm{~m}^{-3}\right)$ & $850-900$ & $850-900$ & - & $860-900$ \\
\hline $\begin{array}{l}\text { Cinematic viscosity at } 40^{\circ} \mathrm{C}\left(\mathrm{Mm}^{2}\right. \\
\left.\mathrm{s}^{-1}\right)\end{array}$ & $3-6$ & $3-6$ & $1.9-6.0$ & $3.50-5.00$ \\
\hline Water content $\left(\mathrm{mg} \mathrm{kg}^{-1}\right)$ & 500 & $380^{b}$ & - & 500 \\
\hline Acidity index $\left(\mathrm{mg} \mathrm{KOH} \mathrm{g}^{-1}\right)$ & 0.50 & 0.50 & 0.50 & 0.50 \\
\hline
\end{tabular}




\begin{tabular}{|c|c|c|c|c|}
\hline Ester content /wt. \% & 96.5 & 96.5 & - & 96.5 \\
\hline Free glycerin /wt. \% & 0.02 & 0.02 & 0.02 & 0.02 \\
\hline Total glycerin /wt. \% & 0.25 & 0.25 & 0.240 & 0.25 \\
\hline $\begin{array}{l}\text { Monoglycerides /wt. \% } \\
\text { Diglycerides /wt.\% } \\
\text { Triglycerides /wt.\% }\end{array}$ & Note ${ }^{(c)}$ & $\begin{array}{l}0.80 \\
0.20 \\
0.20\end{array}$ & - & $\begin{array}{l}0.80 \\
0.20 \\
0.20\end{array}$ \\
\hline $\begin{array}{c}\text { Methanol or ethanol content / wt. } \\
\qquad \% \\
(\% \mathrm{wt})\end{array}$ & 0.20 & 0.20 & 0.20 & 0.20 \\
\hline lodine index $\left(\mathrm{g}_{\left.100 \mathrm{~g}^{-1}\right)}\right.$ & Note $^{c}$ & Note ${ }^{c}$ & - & 120 \\
\hline
\end{tabular}

${ }^{\mathrm{a}}$ Bulk density: determined at $20{ }^{\circ} \mathrm{C}$ according to ANP (Brazilian standard) and at $15{ }^{\circ} \mathrm{C}$ according to the European standard.

${ }^{b}$ This limit was valid until January 2013. From January 2013 until December 2013, the water content limit was $350 \mathrm{mg} \mathrm{Kg}^{-1}$. From January 2014 onward, the water content has been 200 $\mathrm{mg} \mathrm{Kg}^{-1}$.

${ }^{\mathrm{C}}$ The result must be noted by the biodiesel producer and reported to the ANP.

Table 4. Characterization of the FAME and FAEE esters from the transesterification of soybean oil using basic resin

\begin{tabular}{|c|c|c|c|c|c|}
\hline \multirow{2}{*}{ Characteristics } & \multirow{2}{*}{ FAME } & \multirow{2}{*}{ FAEE } & \multicolumn{3}{|c|}{ Test Methods } \\
\hline & & & ABNT NBR & ASTM D & EN ISO \\
\hline Bulk density at $20^{\circ} \mathrm{C}\left(\mathrm{kg} \mathrm{m}^{-3}\right)$ & 879.8 & 887.6 & $7148^{37}$ & $1298^{22}$ & $3675^{38}$ \\
\hline $\begin{array}{c}\text { Cinematic viscosity at } 40^{\circ} \mathrm{C} \\
\left(\mathrm{Mm}^{2} \mathrm{~s}^{-1}\right)\end{array}$ & 4.5 & 7.8 & $10441^{43}$ & $445^{21}$ & $3104^{42}$ \\
\hline Water content $\left(\mathrm{mg} \mathrm{kg}^{-1}\right)$ & 371 & 667 & - & $6304^{44}$ & $12937^{45}$ \\
\hline Acidity index $\left(\mathrm{mg} \mathrm{KOH} \mathrm{g}^{-1}\right)$ & 0.10 & 0.14 & $\begin{array}{c}14448^{41} \\
-\end{array}$ & $\begin{array}{c}664^{39} \\
-\end{array}$ & $14104^{40}$ \\
\hline Ester content /wt. \% & 90.0 & 82.0 & $15764^{34}$ & - & $14103^{33}$ \\
\hline
\end{tabular}




\begin{tabular}{|c|c|c|c|c|c|}
\hline Free glycerin /wt. \% & 0.003 & 0.003 & $\begin{array}{l}15341^{29} \\
15771^{32}\end{array}$ & $\begin{array}{c}6584^{27} \\
-\end{array}$ & $\begin{array}{l}14105^{28} \\
\text { EN } 14106\end{array}$ \\
\hline Total glycerin /wt. \% & 0.023 & 0.690 & $\begin{array}{l}15344^{31} \\
15771^{32}\end{array}$ & $6584^{27}$ & $\begin{array}{l}14105^{28} \\
\text { EN } 14106\end{array}$ \\
\hline Monoglycerides /wt. \% & 0.0271 & 0.0433 & $15342^{30}$ & $6584^{27}$ & $\begin{array}{l}14105^{28} \\
\text { EN } 14106\end{array}$ \\
\hline Diglycerides /wt. \% & 0.0136 & 0.2189 & $15342^{30}$ & $6584^{27}$ & $14105^{28}$ \\
\hline Triglycerides /wt. \% & 0.1082 & 4.6694 & $15344^{31}$ & - & $14105^{28}$ \\
\hline $\begin{array}{l}\text { Methanol or ethanol content } \\
\qquad \begin{array}{c}\text { /wt. } \% \\
\text { (\% wt) }\end{array}\end{array}$ & 0.0143 & 0.0588 & $15343^{36}$ & - & $14110^{35}$ \\
\hline lodine index (g $\left.100 \mathrm{~g}^{-1}\right)$ & 129.30 & 116.39 & - & - & $14111^{46}$ \\
\hline
\end{tabular}

It is possible to observe that there are no significant differences between the limits specified in the standards consulted for many characteristics studied (Table 3). The Brazilian standards ANP 14 and ANP 07 have ten specifications with the same limits as the European standard EN 14214 and three limits similar to the American ASTM 6751. ${ }^{14-17}$

According to the American standard, the values of apparent density, water content, ester content, mono, di and tri-glycerides and iodine index do not need to be determined.

The limits for kinematic viscosity and water content vary between the standards investigated. In the European one, the kinematic viscosity is more restrictive (3.5 to $5.0 \mathrm{Mm}^{2} \mathrm{~s}^{-1}$ ) than in the Brazilian standard (3.0 to $6.0 \mathrm{Mm}^{2} \mathrm{~s}^{-1}$ ), while in the American version this parameter is broader. ${ }^{14-17}$

The new Brazilian regulations lower the water content threshold of $500 \mathrm{ppm}$ to 200 $\mathrm{ppm}$. This is because the substitution of BS50 diesel oil (diesel with $50 \mathrm{ppm}$ sulfur) by BS10 (diesel with 10 ppm sulfur) from January 1 , 2013. Diesel $B$ is added to biodiesel according to ANP recommendations. Nowadays, $5 \% \mathrm{v} / \mathrm{v}$ of biodiesel in diesel is required according to Art. 1 of ANP Resolution 14 (2012). The presence of water is a parameter with high impact on biodiesel quality. Biodiesel is susceptible to water incorporation during its transport, handling and storage, resulting in contamination and degradation, corrosion of tanks and biomass generation. The biomass generation can provoke sludge formation and consequently the obstruction of injector systems and pumps. ${ }^{52}$

Comparing the values obtained experimentally presented in Table 4 with the specifications of Table 3 , it is possible to observe that the FAME ester obtained in this work can be classified as biodiesel under the main parameters analyzed, but a slight adjustment in ester content is necessary according to the limits established in Brazilian and European standards, and also to the water content according to the new Brazilian standard (ANP 14). In relation to FAEE ester, the values of viscosity, water content, ester content, total glycerin and triglycerides are outside the prescribed limit, indicating the need for experimental adjustments to obtain 
a product compliant with the regulations analyzed.

\section{Conclusions}

The anionic resin Amberlyst-260H (with free hydroxyl ions) was more efficient than the cationic resin Amberlyst 15WET (with sulfonic acid groups) for the conversion of soybean oil into FAME and FAEE. The conversion of soybean oil to FAME by employing the anionic resin was $100 \%$ by using $12.5 \mathrm{~mol} \%$ of resin, alcohol:oil molar ratio of 100:1 and reaction time of $8 \mathrm{~h}$. In turn, the conversion of oil to FAEE reached $100 \%$ by using $50.0 \mathrm{~mol} \%$ of resin, alcohol:oil molar ratio of 150:1 and reaction time of 24 h. The FAME esters produced in this work can be classified as biodiesel according to the rules established by ASTM 6751(2008), EN 14214 (2003) and the Brazilian National Petroleum, Natural Gas and Biofuels Agency (ANP), contained in Resolutions14 (2012) and 07 (2008). However, for FAEE esters, some parameters, such as viscosity, water content and total glycerin, need to be optimized.

\section{Acknowledgements}

We acknowledge the financial support from the Fundação Coordenação de Aperfeiçoamento de Pessoal de Nível Superior (CAPES), Conselho Nacional de Desenvolvimento Científico e Tecnológico (CNPq) and Fundação Carlos Chagas de Amparo à Pesquisa do Estado do Rio de Janeiro (FAPERJ). We also express thanks to Rohm and Haas Química Ltda for donating the resin, Professor Alcino Palermo de Aguiar (Organic Chemistry Department, Instituto Militar de Engenharia) for the SEM analyses, Professor Elizabeth Roditi Lachter and Rosane A. S. San Gil (Chemistry Institute, Universidade Federal do Rio de Janeiro) for the $H^{1}$ RMN analyses and Viviane Leite for help in preparing the chemical abstract.

\section{References}

${ }^{1}$ Li, J.; Fu, Y.-J.; Qu, X.-J.; Wang, W.; Luo, M.; Zhao, C.-J.; Zu, Y.-G. Biodiesel production from yellow horn (Xanthoceras sorbifolia Bunge.) seed oil using ion exchange resin as heterogeneous catalyst. Bioresource Technology 2012, 108, 112. [CrossRef]

${ }^{2}$ Yusuf, N. N. A. N.; Kamarudin, S. K.; Yaakub, Z. Overview on the current trends in biodiesel production. Energy Conversion Management 2011, 52, 2741. [CrossRef]

${ }^{3}$ Costa, I. C. R.; Leite, S. G. F.; Leal, I. C. R.; Miranda, L. S. M.; Souza R. O. M. A. Thermal Effect on the Microwave Assisted Biodiesel Synthesis Catalyzed by Lipases. Journal of the Brazilian Chemical Society 2011, 22, 1993. [CrossRef]

${ }^{4}$ Tan, T.; Lu, J.; Nie, K.; Deng, L.; Wang, F. Biodiesel production with immobilized lipase: A review. Biotechnology Advances 2010, 28, 628. [CrossRef]

${ }^{5}$ Sani, Y. M.; Daud, W. M. A. W.; Aziz, A. R. A. Activity of solid acid catalysts for biodiesel production: A critical review. Applied. Catalysis A: General 2014, 470, 140. [CrossRef]

${ }^{6}$ Su, F.; Guo, Y. Advancements in solid acid catalysts for biodiesel production. Green Chemistry 2014, 16, 2934. [CrossRef]

7 Pinto, A. C.; Guarieiro, L. L. N.; Rezende, M. J. C.; Ribeiro, N. M.; Torres, E. A.; Lopes, W. A.; Pereira, P. A. P.; Andrade, J. B. Biodiesel: An Overview. Journal of the Brazilian Chemical Society 2005, 16, 1313. [CrossRef]

${ }^{8}$ Rezende, S. M.; Reis, M. C.; Reid, M. G.; Silva Jr, P. L.; Coutinho, F. M. B.; San Gil, R. A. S.; Lachter, E. R. Transesterification of vegetable oils promoted by poly(styrene divinylbenzene) and poly(divinylbenzene). Applied Catalysis A: General. 2008, 349, 198. [CrossRef]

${ }^{9}$ Shibasaki-Kitakawa, N.; Honda, H.; Kuribayashi, H.; Toda, T.; Fukumura, T.; Yonemoto, T. Biodiesel production using anionic ion-exchange resin as heterogeneous 
catalyst. Bioresource Technology 2007, 98, 416. [CrossRef]

${ }^{10}$ Andrijanto, E.; Dawson, E. A.; Brown, D. R. Hypercrosslinked polystyrene sulphonic acid catalysts for the esterification of free fatty acids in biodiesel synthesis. Applied Catalysis B: Environmental 2012, 115-116, 261. [CrossRef]

${ }^{11}$ Galia, A.; Scialdone, O.; Tortorici, E. Transesterification of rapeseed oil over acid resins promoted by supercritical carbon dioxide. The Journal of Supercritical Fluids 2011, 56, 186. [CrossRef]

12 Reis, S. C. M.; Lachter, E. R.; Nascimento, R. S. V.; Rodrigues Jr, J. A.; Reid, M. G. Transesterification of brazilian vegetable oils with methanol over ion-exchange resins. Journal of the American Oil Chemists' Society 2005, 82, 661. [CrossRef]

13 Lotero, E.; Liu, Y.; Lopez, D. E.; Suwannakarn, K.; Bruce, D. A.; Goodwin Jr., J. G. Synthesis of Biodiesel via Acid Catalysis. Industrial \& Engineering Chemistry Research 2005, 44, 5353. [CrossRef]

14 Brazilian National Petroleum, Natural Gas and Biofuels Agency, ANP. Resolution ANP 07. 2008. Available in: <http://nxt.anp.gov.br/nxt/gateway.dll/leg/r esolucoes anp/2008/mar\%C3\%A7o/ranp\%20 7\%20-\%202008.xml>. Accessed in: July 2014.

${ }^{15}$ Brazilian National Agency of Petroleum, Natural Gas and Biofuels ANP. Resolution ANP $14.2012 . \quad$ Available in: <http://nxt.anp.gov.br/nxt/gateway.dll/leg/r esolucoes anp/2012/maio/ranp $\% 252014 \% 25$ 20-\%25202012.xm>. Accessed in: December 2014.

${ }^{16}$ ASTM D6751-11a. Standard Specification for Biodiesel Fuel Blend Stock (B100) for Middle Distillate Fuels. ASTM International, West Conshohocken. 2011.

17 EN 14214. Liquid petroleum products Fatty acid methyl esters (FAME) for use in diesel engines and heating applications Requirements and test methods. European Committee for Standardization, Brussels. 2013.
${ }^{18}$ American Oil Chemists Society. Official methods and recommended practices of the American Oil Chemists Society. 4th ed. Champaign, A.O.C.S: USA, 1995.

${ }^{19}$ Bobbio F. O.; Bobbio, P. A.; Introdução a Química dos Alimentos, 2nd ed., Livraria Varela: São Paulo. 1992.

${ }^{20}$ Saytyarthi, J. K.; Srinivas, D.; Ratnasamy, P. Estimation of Free Fatty Acid Content in Oils, Fats, and Biodiesel by $1 \mathrm{H}$ NMR Spectroscopy. Energy \& Fuels, 2009, 23, 2273. [CrossRef]

${ }^{21}$ ASTM D445-09. Standard Test Method for Kinematic Viscosity of Transparent and Opaque Liquids (and Calculation of Dynamic Viscosity), ASTM International, West Conshohocken. 2009.

22 ASTM D1298-12b. Standard Test Method for Density, Relative Density, or API Gravity of Crude Petroleum and Liquid Petroleum Products by Hydrometer Method, ASTM International, West Conshohocken. 2012.

${ }^{23}$ ASTM D 1895-96. Standard Test Methods for Apparent Density, Bulk Factor, and Pourability of Materials. Annual Book of ASTM Standards. ASTM International, West Conshohocken. 2010.

${ }^{24}$ Souza, M. A. V.; Santa Maria, L. C.; Costa, M. A. S.; Hui, W. S.; Costa, L. C.; Filho, H. C. A.; Amico, S. C. Synthesis, Characterization and Evaluation of Phosphorylated Resins in the Removal of $\mathrm{Pb}^{2+}$ from Aqueous Solution. Polymer Bulletin 2011, 67, 237. [CrossRef]

${ }^{25}$ Kunin, R.; Ion Exchange Polymers, 2nd. ed., R. E. Krieger: Melbourne, Floride, 1972.

${ }^{26}$ Gelbard, G.; Brès, O.; Vargas, R. M.; Vielfaure, F.; Schuchardt, U. F. ${ }^{1} \mathrm{H}$ nuclear magnetic resonance determination of the yield of the transesterification of rapeseed oil with methanol. Journal of the American Oil Chemists' Society 1995, 72, 1239. [CrossRef]

27 ASTM D6584. Determination of total monoglyceride, total diglyceride, total triglyceride, and free and total glycerin in b100 biodiesel methyl esters by gas chromatography. ASTM International, West Conshohocken.

2007. 
${ }^{28}$ EN14105. Fat and Oil Derivatives-Fatty Acid Methyl Esters (FAME) - Determination of Free and Total Glycerol and Mono-, Di- and Triglyceride Content. European Committee for Standardization, Brussels. 2011.

${ }^{29}$ Associação Brasileira de Normas Técnicas. ABNT NBR 15341: Biodiesel - Determination of free glycerol in castor oil biodiesels by gas chromatography. 2012.

${ }^{30}$ Associação Brasileira de Normas Técnicas. ABNT NBR 15342: Biodiesel - Determination of monoglycerides, diglycerides content of castor oil biodiesel by gas chromatography. 2009.

${ }^{31}$ Associação Brasileira de Normas Técnicas. ABNT NBR 15344: Biodiesel - Determination of total glycerin and triglycerides contents oil biodiesels. 2010.

${ }^{32}$ Associação Brasileira de Normas Técnicas. ABNT NBR 15771: Biodiesel - Determination of free glycerin (volumetric method). 2009.

${ }^{33}$ EN 14103. Fat and oil derivatives - Fatty Acid Methyl Esters (FAME) - Determination of ester and linolenic acid methyl ester contents. European Committee for Standardization, Brussels. 2011.

${ }^{34}$ Associação Brasileira de Normas Técnicas. ABNT NBR 15764: Biodiesel - Determination of ester by gas chromatography. 2009.

${ }^{35}$ EN 14110. Fat and oil derivatives - Fatty Acid Methyl Esters (FAME) - Determination of methanol content. European Committee for Standardization, Brussels. 2003.

${ }^{36}$ Associação Brasileira de Normas Técnicas. ABNT NBR 15343: Biodiesel - Determination of methanol or/and ethanol concentrations in fatty acid esters by gas chromatography. 2012.

${ }^{37}$ Associação Brasileira de Normas Técnicas. ABNT NBR 7148: Petroleum and Petroleum Products - Determination of specific mass, relative density and ${ }^{\circ} \mathrm{API}$ - Method of densimetry. 2013.

${ }^{38}$ EN ISO 3675. Crude petroleum and liquid petroleum products - Laboratory determination of density - Hydrometer method. 1998.
${ }^{39}$ ASTM D664. Standard Test Method for Acid Number of Petroleum Products by Potentiometric Titration. ASTM International, West Conshohocken. 2011.

${ }^{40}$ EN 14104. Fat and Oil Derivatives - Fatty Acid Methyl Esters (FAME), Determination of Acid Value, European Committee for Standardization, Brussels. 2003.

${ }^{41}$ Associação Brasileira de Normas Técnicas. ABNT NBR 14448: Petroleum Products Determination of acidy degree by potenciometry titulation. 2013.

${ }^{42}$ EN ISO 3104. Petroleum products Transparent and opaque liquids -Determination of kinematic viscosity and calculation of dynamic viscosity. 1994.

${ }^{43}$ Associação Brasileira de Normas Técnicas. ABNT NBR 10441: Petroleum products Transparent and opaque liquids Determination of kinematic viscosity and calculation of dynamic viscosity. 2014.

${ }^{44}$ ASTM D6304. Standard Test Method for Determination of Water in Petroleum Products, Lubricating Oils, and Additives by Coulometric Karl Fischer Titration, ASTM International, West Conshohocken. 2007.

${ }^{45}$ EN ISO 12937. Petroleum products Determination of water - Coulometric Karl Fischer titration method. 2000.

${ }^{46}$ EN 14111. Fat and oil derivatives - Fatty Acid methyl Esters (FAME) - Determination of iodine value. European Committee for Standardization, Brussels. 2003.

${ }^{47}$ Silverstein, R. M.; Webster, F. X.; Kiemle D. J.; Spectrometric Identification of Organic Compounds, 7th. Ed., Wiley Global Education: London. 2005.

${ }^{48}$ Kim, M.; Salley, S. O.; Ng, K. Y. S. Transesterification of Glycerides Using a Heterogeneous Resin Catalyst Combined with a Homogeneous. Catalys. Energy \& Fuels 2008, 22, 3594. [CrossRef]

${ }^{49}$ Schuchardt, U.; Sercheli, R.; Vargas, R. M. Transesterification of Vegetable Oils: a Review. Journal of the Brazilian Chemistry Society 1998, 9, 199. [CrossRef] 
${ }^{50}$ He, B.; Shao, Y.; Ren, Y.; Li, J.; Cheng, Y. Continuous biodiesel production from acidic oil using a combination of cation- and anionexchange resins. Fuel Processing Tecnology 2015, 130, 1. [CrossRef]

${ }^{51}$ Shibasaki-Kitakawa, N.; Hiromori, K.; Ihara, T.; Nakashima, K.; Yonemoto, T. Production of high quality biodiesel from waste acid oil obtained during edible oil refining using ion- exchange resin catalysts. Fuel 2015, 139, 11. [CrossRef]

${ }^{52}$ National Biodiesel Board (2009) Fuel Quality and Performance Guide. Available in: $<$ http://www.biodiesel.org/docs/ffsperformace usage/fuel-quality-andperformance-guide.pdf?sfvrsn=6>. Accessed in: 25 March 2013. 